\title{
Pengetahuan tentang Anemia dengan Kadar Hemoglobin Remaja Putri
}

\author{
Arifarahmi \\ Program Studi D III Kebidanan, STIKesBaiturrahim, Jambi, Indonesia \\ Email : ami.arifa05@gmail.com
}

Submitted : 30/08/2021

Accepted: 10/09/2021

Published: 15/09/2021

\begin{abstract}
WHO mentions that anemia is the 10 biggest health problems at this time. One of the groups at high risk of suffering from anemia are school-age children and adolescents. Lack of one nutrient can cause a disease in the form of a deficiency disease. In adolescents, iron deficiency can reduce work performance and learning achievement in addition to decreased body resistance to infectious diseases.Knowledge about anemia is important in preventing adolescent girls from having normal hemoglobin levels. If the knowledge of adolescent girls about anemia is good, it is hoped that will not experience anemia. The purpose of this study was to determine the relationship between knowledge about anemia and hemoglobin levels in adolescent girls. The study was carried out at SMPN 14 Jambi City, and used an analytical research design. The research population was adolescent girls, with 30 respondents. The research instrument used a questionnaire and a hemoglobin measurement tool, as well as an informed consent sheet and a permit signed by the parents. The data collected were analyzed by univariate and bivariate.The results of this study showed that 30 respondents, most of the adolescent girls have good knowledge, namely 26 people (86.7\%), and 29 people who do not have anemia (96.7\%). The results of the bivariate test showed that there was no relationship between knowledge about anemia and hemoglobin levels p-value $=$ 0.867. Furthermore, it is necessary for adolescent girls to check their hemoglobin levels regularly as an effort to determine their health status.
\end{abstract}

Keywords: adolescent girls, hemoglobin level, knowledge about anemia

\begin{abstract}
Abstrak
WHO menyebutkan bahwa anemia merupakan 10 masalah kesehatan terbesar pada saat ini. Kelompok yang beresiko tinggi menderita anemia salah satunya adalah anak usia sekolah dan remaja. Kekurangan salah satu zat gizi dapat menimbulkan penyakit berupa penyakit defisiensi. Pada remaja kekurangan zat besi dapat menurunkan prestasi kerja dan prestasi belajar selain turunnya ketahanan tubuh terhadap penyakit infeksi. Pengetahuan tentang anemia merupakan hal penting dalam upaya mencegah remaja putri untuk memiliki kadar hemoglobin yang normal. Jika pengetahuan remaja putri tentang anemia baik maka harapannya remaja putri tidak mengalami anemia.Tujuan penelitian ini untuk mengetahui hubungan pengetahuan tentang anemia dengan kadar hemoglobin pada remaja putri. Penelitian dilaksanakan di SMPN 14 Kota Jambi, serta menggunakan desain penelitian analitik. Populasi penelitian adalah remaja putri, dengan responden 30 orang. Instrument penelitian menggunakan kuesioner dan alat pengukuran hemoglobin, serta ada lembar informed concent dan surat izin yang telah ditandatangan oleh orangtua. Data yang terkumpulkan di analisis secara univariat dan bivariat. Hasil penelitian ini menunjukkan bahwa dari 30 responden sebagian besar remaja putri memiliki pengetahuan baik yaitu 26 orang (86,7\%), dan yang tidak mengalami anemia sebanyak 29 orang $(96,7 \%)$. Hasil uji bivariat didapatkan bahwa tidak ada hubungan pengetahuan tentang anemia dengan kadar hemoglobin $p$-value $=0.867$. Selanjutnya perlu bagi remaja putri untuk melakukan pengecekan kadar hemoglobin secara berkala sebagai salah satu upaya untuk mengetahui status kesehatan dirinya.
\end{abstract}

Kata Kunci : kadar hemoglobin, pengetahuan tentang anemia, remaja putri 


\section{PENDAHULUAN}

Anemia merupakan masalah gizi yang banyak terdapat diseluruh dunia yang tidak hanya terjadi di negara berkembang tetapi juga di negara maju. Penderita anemia diperkirakan dua milyar dengan prevalensi terbanyak di Asia dan Afrika. Menurut WHO menyebutkan bahwa anemia merupakan 10 masalah kesehatan terbesar pada saat ini. Kelompok yang beresiko tinggi menderita anemia salah satunya adalah anak usia sekolah dan remaja (Briawan, 2016).

Anemia merupakan suatu keadaan dimana kadar hemoglobin ( $\mathrm{Hb}$ ) dalam darah yang kurang dari normal. Anemia berdampak pada menurunnya produktivitaskerja ataupun kemampuan akademis disekolah karena tidak adanya gairah belajardan konsentrasi (Supariasa dkk, 2014).

Masalah gizi remaja akan berdampak negatif pada tingkat kesehatan masyarakat. Pada dasarnya masalah gizi pada remaja timbul karena perilaku gizi yang salah, yaitu ketidakseimbangan antara konsumsi gizi dengan kecukupan gizi yang dianjurkan. Kekurangan salah satu zat gizi dapat menimbulkan penyakit berupa penyakit defisiensi. Pada remaja kekurangan zat besi dapat menurunkan prestasi kerja dan prestasi belajar selain turunnya ketahanan tubuh terhadap penyakit infeksi (Badriah, 2011).

Selain itu, anemia yang disebabkan oleh kekurangan zat besi dapat menyebabkan risiko pendarahan pada waktu melahirkan. Wanita dan remaja putri membutuhkan zat besi dua kali lebih banyak dari pada pria atau remaja putra karena mengalami haid dan banyak mengeluarkan darah waktu melahirkan dan zat besi diperlukan untuk memproduksi darah (Proverawati, 2009).

Penelitian di India, Bangladesh dan Vietnam pemberian tablet tambah darah dilakukan 1 kali seminggu dan berhasil menurunkan prevalensi anemia di Negara tersebut. Penelitian di kupang (NTT) pemberian tablet tambah darah secara mingguan selama 16 minggu mampu meningkatkan kadar hemoglobin. Pemerintah menetapkan kebijakan program pemberian tablet tambah darah pada remaja putri dilakukan setiap 1 kali seminggu dan sesuai dengan Permenkes yang berlaku. (Kemenkes RI, 2016).

\section{METODE PENELITIAN}

Penelitian ini merupakan penelitian analitik yang bertujuan untuk mengetahui hubungan pengetahuan tentang anemia remaja putri dengan kadar hemoglobin. Populasi penelitian ini adalah remaja putri di SMPN 14 Kota Jambi tahun 2019 yang duduk di kelas VII. Sampel pada penelitian ini berjumlah 30 responden dengan kriteria inklusi siswi yang telah mendapatkan persetujuan orangtua untuk dilakukan pengukuran kadar hemoglobin dan hadir di sekolah saat penelitian dilakukan.Arikunto (2012).

Instrument dan alat yang digunakan dalam penelitian ini menggunakan kuesioner yang terdiri dari 18 pertanyaan mengenai pengetahuan tentang anemia meliputi (pengertiananemia, jenis anemia, tanda dan gejala, penyebab anemia, cara mengetahui anemia, dampak anemia, cara mencegah anemia dan cara mengatasi anemia, kadar $\mathrm{Hb}$ normal). Alat yang digunakan untuk pengukuran kadar hemoglobin menggunakan quik check.Siswi terlebih dahulu menjawab kuesioner secara lengkap dan selanjutnya dilakukan pengukuran kadar hemoglobin. Waktu penelitian dilaksanakan pagi hari.Selanjutnya hasil dari pengisian kuesioner dilakukan pengolahan data yang meliputi pengecekan data, pemberian kode, pemberian nilai dan memasukan data serta di analisis. Klasifikasi untuk variabel 
pengetahuan dikatakan baik jika skor jawaban 76\%-100\%. Pengetahuan kurang jika skor jawaban $\leq 75 \%$.Pada variabel kadar hemoglobin dengan klasifikasi tidak anemia jika kadar hemoglobin $\geq 12 \mathrm{~g} / \mathrm{dl}$. Anemia jika kadar hemoglobin $<12 \mathrm{~g} / \mathrm{dl}$.

Etika dalam penelitian ini mengunakan lembar persetujuan (informed concent), lembar persetujuan orangtua, tidak mencantumkan nama di lembar kuesioner dan menjaga kerahasiaan responden. Notoadmodjo (2010).

\section{HASIL DAN PEMBAHASAN Karakteristik responden}

Karakteristik umum responden menjadi penting agar didapatkan gambaran yang jelas mengenai karakteritsik responden. Data yang di tampilkan pada karakteristik responden yaitu umur. Distribusi karakteristik responden terlihat pada tabel berikut:

\section{Tabel.1. Distribusi umur remaja putri}

\begin{tabular}{lll}
\multicolumn{1}{c}{ Karakteritik } & n & \% \\
\hline Umur & & \\
13 Tahun & 6 & 20 \\
14 Tahun & 22 & 73,3 \\
15 Tahun & 2 & 6,7 \\
Jumlah & 30 & 100 \\
\hline
\end{tabular}

Berdasarkan tabel 1 di peroleh gambaran responden bahwa dari 30 responden sebagian besar berada pada umur 14 tahun berjumlah 22 responden $(73,3 \%)$.

\section{Pengetahuan tentang anemia}

Pada penelitian ini digambarkan pengetahuan tentang anemia Berikut hasilnya dapat di lihat pada tabel :

Tabel.2 Pengetahuan remaja putri tentang anemia

\begin{tabular}{lcc}
\hline \multicolumn{1}{c}{ Pengetahuan } & n & \% \\
\hline Baik & 26 & 86,7 \\
Kurang & 4 & 13,3 \\
$\quad$ Jumlah & 30 & 100 \\
\hline
\end{tabular}

Berdasarkan tabel 2 di peroleh hasil dari 30 responden sebagian besar memiliki pengetahuan baik yaitu 26 responden $(86,7 \%)$.

\section{Kadar hemoglobin remaja putri}

Pada penelitian ini dilakukan pengukuran kadar hemoglobin. Berikut hasilnya dapat di lihat pada tabel 3 .

Tabel.3 Kadar hemoglobin remaja putri

\begin{tabular}{ccc}
\hline $\begin{array}{c}\text { Kadar } \\
\text { Hemoglobin }\end{array}$ & n & \% \\
\hline Tidak anemia & 29 & 96,7 \\
Anemia & 1 & 3,3 \\
Jumlah & 30 & 100 \\
\hline
\end{tabular}

Berdasarkan tabel 3 di peroleh dari 30 responden sebagian besar remaja putri tidak anemia yaitu 29 responden $(96,7 \%)$.

Berdasaarkan hasil penelitian yang telah dilakukan, karakteristik responden sebagian besar berada pada usia 14 tahun. Hal ini menunjukkan bahwa remaja putri berada dalam rentang usia remaja menengah. (Cahyaningsih, 2011).Pada usia ini remaja putri mengalami perubahan fisik dan psikologis. Biasanya menstruasi sudah terjadi. Perubahan fisik, remaja putri terjadi pada perubahan bentuk ukuran tubuh. Hal ini diikuti dengan munculnya tanda-tanda perubahan seks sekunder dan primer. (Kumalasari, 2012).

Pada usia ini remaja putri biasanya menjadi lebih sensitif dan umumnya cenderung lebih banyak makan. Namun, disadari bahwa remaja putri saat ini lebih memilih untuk diet karena adanya persepsi takut gemuk. Sehingga pada masa ini, remaja putri perlu mendapatkan informasi bahwa seiring dengan telah datangnya menstruasi dan perubahan fisik maka dalam upaya mendukung pertumbuhan dan perkembangan yang optimal selama masa remaja, hendaknya remaja putri tetap memperhatikan asupan nutrisi menu seimbang dengan memperhatikan pola hidup sehat agar remaja putri tetap sehat dan dapat produktif selama masa sekolah.

Berdasarkan hasil penelitian yang diperoleh melalui pengisian kuesioner pengetahuan tentang anemia bahwa dari 30 responden, yang berpengetahuan baik sebanyak 26 responden $(86,7 \%)$. 
Pengetahuan merupakan hasil dari tahu dan ini terjadi setelah orang melakukan pengindraan terhadap satu objek tertentu. Penginderaan terjadi melalui panca indra manusia yakni, indra penglihatan, pendengaran, penciuman, rasa dan raba. Sebagian besar pengetahuan manusia diperoleh melalui mata dan telinga (Notoatmodjo, 2010).

Pengetahuan umumnya datang dari pengalaman dan informasi yang didapatkan melalui guru, teman, keluarga, orangtua, media informasi seperti internet dan majalah ataupun koran. Pengetahuan remaja yang sebagaian besar baik ini menunjukkan bahwa remaja putri aktif dalam mendapatkan informasi mengenai anemia. Pada kondisi saat ini sangat disadari kemudahan akses bagi remaja untuk mendapatkan informasi baik tentang informasi umum ataupun tentang kesehatan.

Untuk itu perlu adanya kerjasama yang baik antara pihak sekolah dan orangtua. Pendampingan dari orangtua selama dirumah dan informasi ataupun edukasi dari tenaga kesehatan juga sangat diperlukan agar informasi yang diserap oleh remaja putri adalah benar-benar informasi yang baik dan benar.Mengingat dari hasil penelitian masih didapatkan pengetahuan kurang tentang anemia dengan jumlah responden 4 orang (13.3\%) sehingga masih sangat diperlukan upaya dan peran dari tenaga kesehatan untuk dapat terus memberikan edukasi tentang anemia agar remaja terhindar dari kejadian anemia.

Hasil penelitian ini sejalan dengan penelitian yang dilakukan oleh Romandani dan Rahmawatidi SMPN 237Jakarta tahun 2019 didapatkan hasil sebanyak 87 orang memiliki pengetahuan anemia yang baik $(87 \%)$. Selanjutnya penelitian yang sama juga telah dilakukan oleh Adnyana dkk di SMP Dwijendra Denpasar tahun 2020. Hasil penelitian menunjukkan bahwa remaja putri mayoritas berada pada kategori pengetahuan baik yaitu 48 responden (78\%).
Hasil penelitian tentang kadar hemoglobin remaja putri di SMPN 14 didapatkan sebagian besar tidak mengalami anemia sebanyak 29 responden (96,7\%). Berdasarkan data WHO (2010), kejadian anemia pada remaja putri yang ada di negara berkembang sekitar 27\%. Namun secara global prevalensi anemia yaitu sekitar 51\% dengan prevalensi balita $43 \%$, anak usia sekolah $37 \%$, pria dewasa $18 \%$, dan wanita tidak hamil $35 \%$.

Berdasarkan data WHO diatas dapat dilihat perbedaan, bahwa angka kejadian anemia pada penelitian hanya 3,3\%. Walaupun angka kejadian ini kecil tetapi kejadian anemia ada pada remaja putri. Menurut penelitian yang dilakukan Nurjanah SMP Negeri 2 Garawangi Kabupaten Kuningan tahun 2021, angka kejadian remaja yang mengalami anemia $82 \%$, dan remaja tidak anemia $28 \%$. Berdasarkan hasil penelitian Nurjanah ini, maka terdapat perbedaan hasil mengenai angka kejadian anemia dengan hasil penelitian yang peneliti lakukan.

Anemia pada remaja dapat dicegah dengan asupan pola makan gizi seimbang. Makanan yang banyak mengandung sumber zat besi contohnya ikan, daging dan unggas. Sumber makanan lain yaitu konsumsi buah-buahan yang juga meningkatkan penyerapan zat besi karena mengandung Vitamin C tinggi seperti jeruk, pepaya, mangga dan jambu biji.

Menurut penelitian Ningsih tahun 2012 di SMPN 3 Kecamatan Tebing Kabupaten Karimun didapatkan mayoritas responden dengan pola makan tidak sehat yaitu 44 responden $(71 \%)$. Faktor resiko terjadinya anemia salah satunya adalah mengenai pola makan yang tidak sehat pada remaja. Hal ini dapat menjadi tantangan bagi sekolah dan instansi kesehatan agar dapat terus berupaya memberikan edukasi kepada remaja tentang asupan makanan yang bernilai gizi seimbang.

Hubungan pengetahuan tentang anemia dengan kadar hemoglobin remaja putri 
Pada penelitian ini didapatkan hasil pengetahuan tentang anemia dan kadar hemoglobin remaja putri. Berikut hasilnya dapat di lihat pada tabel4.

Tabel.4 Hubungan pengetahuan tentang anemia dengan kadar hemoglobin

\begin{tabular}{rcccc}
\hline & & Anemia & $\begin{array}{c}\text { pval } \\
\boldsymbol{u e}\end{array}$ \\
\hline Pengetahuan & Tidak & & & \\
Baik & 25 & 1 & 26 & 0.867 \\
& $(96,2 \%)$ & $(3,8 \%)$ & $(100 \%)$ & \\
Kurang & 4 & 0 & 4 & \\
& $(100 \%)$ & $0 \%$ & $(100 \%)$ & \\
& 29 & 1 & 30 & \\
Total & $(96,7 \%)$ & $(3,3 \%)$ & $(100 \%)$ & \\
\hline
\end{tabular}

bahwa dari seluruh remaja putri yang memiliki pengetahuan baik, masih ada yang mengalami anemia 1 orang $(3,8 \%)$. Menurut Handayani (2012) salah satu penyebab seorang remaja putri mengalami anemia yaitu faktor nutrisi: akibat kurangnya jumlah besi total dalam makanan atau kualitas besi yang tidak baik (makanan banyak mengandung serat, rendah vitamin c dan rendah daging).Masalah ini bisa diatasi bila sejak kecil para orangtua dan orangorang dewasa disekitar remaja memberikan contoh hidup sehatdan memberikan pengetahuan memadai mengenai nutrisi dan ilmu gizinya.

Pengetahuan tentang anemia yang baik pada remaja putri tidak menjamin bahwa seorang remaja tidak mengalami anemia. Dari tabel diatas diketahui bahwa dari seluruh remaja putri yang memiliki pengetahuan kurang sebanyak 4 orang, tetapi tidak mengalami anemia $100 \%$.

Pengetahuan bukanlah menjadi satusatunya faktor penentu seseorang mengalami anemia. Banyak faktor yang menjadi penyebab anemia. Salah satunya seperti yang disebutkan diatas tentang asupan nutrisi yang belum tepat. Adanya penyakit lain seperti infeksi menahun dapat menjadikan seseorang mengalami anemia.

Sejalan dengan penelitian yang dilakukan Budiarti A dkk pada remaja putri yang menderita anemia di Surabaya tahun 2020. Didapatkan hasil bahwaterdapat beberapa faktor penyebab kejadian anemia yang dialami remaja yaitu kurangnya pengetahuan anemia dan asupan gizi sehingga mempengaruhi pemilihan dalam konsumsi makanan yang bergizi, tidak terbiasanya sarapan pagi, adanya kebiasaan minum teh dan kopi yang dilakukan remaja menjadi penyebab terhambatnya proses penyerapan zat besi di dalam tubuh, serta asupan beberapa zat gizi seperti energi, protein, dan vitamin $\mathrm{C}$ yang kurang dari Angka Kecukupan Gizi (AKG) serta asupan zat besi yang defisit pada masing-masing partisipan serta tidak rutinnya remaja putri dalam mengkonsumi tablet Fe merupakan faktor utama menyebabkan partisipan menderita anemia.

Pencegan lebih baik daripada pengobatan, oleh karena itu gaya hidup sehat selama masa remaja sangat penting dilakukan agar dapat menjadi kebiasaan yang baik pada tahap perkembangan usia selanjutnya.

\section{SIMPULAN}

Remaja putri yang memiliki pengetahuan baik yaitu 26 orang $(86,7 \%)$ dan yang tidak mengalami anemia sebanyak 29 orang $(96,7 \%)$. Tidak ada hubungan pengetahuan tentang anemia dengan kadar hemoglobin dengan $p$-value= 0.867

\section{SARAN}

Perlu bagi remaja putri untuk melakukan pengecekan kadar hemoglobin secara berkala sebagai salah satu upaya untuk mengetahui status kesehatan dirinya.

\section{UCAPAN TERIMAKASIH}

Penulis mengucapakan mengucapkan terima kasih kepada Sekolah Tinggi Ilmu Kesehatan Baiturrahim atas bantuan, dana, fasilitas dan surat izinsertakepala sekolah dan guru-guru di SMPN 14 yang telah membantu dan memberikan izin dalam 
melakukan penelitian ini sehingga penelitian dapat berjalan dengan lancar.

\section{DAFTAR PUSTAKA}

Adnyana GANWS, Armini NW, Suarniti NW. Gambaran pengetahuan tentang anemia dan kepatuhan remaja dalam mengkonsumsi tablet tambah darah. Jurnal Ilmiah Kebidanan (The Journal Of Midwifery), 2021;9(1):103-109.

Arikunto S. Prosedur Penelitian. Jakarta: PT Rineka Cipta, 2012.

Badriah, D, L. Gizi dalam Kesehatan Reproduksi. Jakarta: Refika Aditama, 2011.

Budiarti A, Anik S, Wirani NPG. Studi Fenomenologi Penyebab Anemia Pada Remaja Di Surabaya. Jurnal Kesehatan Mesencephalon.2021; 6(2):137-141.

Briawan. Anemia Masalah Gizi pada Remaja Wanita. Jakarta: EGC, 2016.

Cahyaningsih.Pertumbuhan Perkembangan Anak dan Remaja. Jakarta: Trans Info Media, 2011.

Handayani.. Asuhan Keperawatan Pada Kkien dengan Gangguan Hematologi. Jakarta: Salemba Medika.2012.

Kemenkes RI. Pencegahan dan Penanggulangan Anemia Pada Remaja Putridan Wanita Usia Subur. Jakarta, 2016.

Notoatmojo.Metode Penelitian Kesehatan. Jakarta: PT Rineka Cipta, 2010.

Proverawati. Buku Ajar Gizi Untuk Kebidanan. Yogyakarta: Nuha Medika, 2009.

Romandani QF dan Rahmawati T. Hubungan Pengetahuan Anemia Dengan Kebiasaan Makan Pada Remaja Putri Di SMPN 237 Jakarta. Jurnal Persataun Perawat Nasional Indonesia. 2021;4(3):193-202.

Ningsih K, Batubara S. Faktor-faktor yang berhubungan dengan kejadian anemia pada remaja putri di SMPN 3 Kecamatan Tebing KAbupaten
Karimun Tahun 2017. Zona Kebidanan: Program Studi Kebidanan Universitas Batam 2021;8(3): 55-60.

Nurjannah SN, Nunung S, Putri EA. Hubungan Status Gizi Dengan Kejadian Anemia Pada Remaja Putri Di SMP Negeri 2 Garawangi Kabupaten Kuningan. Journal of Midwifery Care.2021;1(02):125-131. Supariasa. Penilaian Status Gizi. Jakarta: EGC. 2012.

WHO. (2010). The World Health Report 2010. Retrieved from Http://Www. Who.Int./Whr/2010/En/Index.Html 